\title{
Evaluation of antioxidant activity and lipid oxidative stability of roasted buckwheat according to in vitro digestive system
}

\author{
Hyun-Gyeong Bae, Seonghyeon Kim, Jae-Cheol Lee, Mi-Ja Kim* \\ Department of Food and Nutrition, Kangwon National University, Samcheok 25949, Korea \\ In vitro digestive system 적용에 따른 볶음 메밀의
항산화 활성 및 유지산화 안정성 평가 \\ 배현경 · 김성현 · 이재철 · 김미자* \\ 강원대학교 식품영양학과
}

\begin{abstract}
An in vitro digestive system simulates the human digestive tract. This study aimed to evaluate antioxidant activity and oxidative stability of roasted buckwheat extracts after treatment with an in vitro digestive system. The buckwheat samples were subjected to the following roasting conditions: $180^{\circ} \mathrm{C}$ for $10 \mathrm{~min}, 180^{\circ} \mathrm{C}$ for $20 \mathrm{~min}, 200^{\circ} \mathrm{C}$ for 10 min, and $200{ }^{\circ} \mathrm{C}$ for $20 \mathrm{~min}$; ethanol extracts of the buckwheat samples were prepared after the in vitro digestive system treatment. Buckwheat samples roasted at $200^{\circ} \mathrm{C}$ for $10 \mathrm{~min}$ showed the highest in vitro antioxidant activities, including 2,2-diphenyl-1-picrylhydrazyl, 2,2'-azino-bis (3-ethylbenzothiazoline-6-sulfonic acid) cation radical-scavenging activity, and ferric-reducing antioxidant power. The total phenolics content of buckwheat roasted at $200^{\circ} \mathrm{C}$ for 10 min was $13.14 \mu \mathrm{mol}$ tannic acid equivalent/g extract, while those of the samples subjected to the other roasting treatments ranged from 7.58 to $9.86 \mu \mathrm{mol}$ tannic acid equivalent/g extract. Furthermore, the synthesis of primary and secondary oxidative products from com oil containing $1,000 \mathrm{ppm}$ buckwheat roasted at $200^{\circ} \mathrm{C}$ for 10 min decreased by $10 \%$ and $20 \%$, significantly, compared to those in the control groups $(p<0.05)$. Overall, the ethanolic extracts of roasted buckwheat obtained after in vitro digestive treatment still possessed relatively high in vitro antioxidant activity. It was found that roasted buckwheat according to in vitro digestion could be used as an antioxidant material.
\end{abstract}

Key words : buckwheat, in vitro digestion, roasting, antioxidant, oxidative stability

서 론

In vitro 소화계(in vitro digestive system)는 인체 내의 매 우 정교하고 복잡한 소화과정을 최대한 비슷한 유사 환경을 만들어 인체내 소화와 비슷한 결과를 얻어낼 수 있는 연구 방법이다(Hur 등, 2009; Hur 등, 2012). 또한 동물이나 사람 을 대상으로 한 식품의 기능성 검증이 가장 정확한 생리활성
결과를 얻을 수 있지만, 시간과 비용이 많이 들어 이러한 in vivo system을 대체할 수 있는 연구방법에 많은 노력과 관심 이 집중되고 있다(Boisen과 Eggum, 1991). In vitro 소화계 연구는 생체 내에서 이루어지는 소화과정을 통한 연구보다 신속하고 단순하며, 비용이 적게 들어 경제적이고 동물실험 이나 인체 적용시험 등에 의한 생명 윤리 문제에서도 자유로 울 수 있다는 장점 등이 있다(Coles 등, 2005). 이러한 체외

*Corresponding author. E-mail : mijakim@kangwon.ac.kr, Phone : +82-33-540-3313, Fax : +82-33-540-3319

Received 18 March 2021; Revised 28 April 2021; Accepted 12 May 2021.

Copyright (c) The Korean Society of Food Preservation.

This is an Open Access article distributed under the terms of the Creative Commons Attribution Non-Commercial License (http://creativecommons.org/licenses/by-nc/4.0) which permits unrestricted non-commercial use, distribution, and reproduction in any medium, provided the original work is properly cited. 
소화 모델의 장점을 이용하여 현재 다양한 식품 및 기능성 물질의 개발에 널리 적용되고 있다. 최근 약 40년간 in vitro 소화계를 적용하여 다양한 식품의 분석 및 개발 관련 연구 논문이 다수 발표되었으며, 식품 속 생체 활성 화합물, 생체 접근성 및 항산화 특성에 대한 식품 매트릭스 연구에 효과적 이라고 보고되고 있다(Lucas-González 등, 2018). Monro 등 (2010)은 in vitro digestion이 생체 내 전분소화율과 혈당 반 응에 대한 예측 인자의 역할을 할 수 있음을 보고하였고, 그 외에 $\mathrm{Ng}$ 와 $\mathrm{See}(2019)$ 는 기능성 식물성 식품에 적용하여 탄 수화물 가수분해 효소 억제 관련 연구를 수행하여 당뇨 예방 기능성 식품 탐색을 발표하는 등 다양한 식품개발 연구에 활 발히 이용되고 있다.

또한 식품을 가공 처리하는 방법 중 가장 널리 사용되는 가열법은 식품 속 물리적, 이화학적 변화를 만들어 영양소나 생리활성 물질의 파괴, 생성 및 증가 등의 다양한 변화를 일 으키며, 이에 관련한 활발한 연구가 진행 중이다(Cho와 Joo, 2012). 식물 가열처리 시 단백질과 결합된 고분자의 페놀성 화합물의 결합 변화 또는 새로운 페놀성 화합물이 생성되어 총 페놀성 화합물 함량이 증가하게 된다고 보고한 바 있다 (Dewanto 등, 2002; Yu J 등, 2005). 이는 가열공정이 식품 개발에 중요한 가공 처리 요소로 특히 곡류 제품 개발에 있어 Schlörmann 등(2020)은 귀리를 가열처리하였을 때 탄수화물 과 단백질의 화학적 결합의 변화로 인하여 불용성 식이섬유 의 감소와 수용성 식이섬유의 증가가 관찰되었다고 보고하였 으며, Majcher 등(2013)은 보리로 만든 시리얼커피를 가열가 공하였을 때 열에 의해 화합물이 합성되어 견과류와 커피의 맛을 생성시킨다는 연구를 발표하였다.

메밀(Fagopyrum esculentum)은 중요한 대체 작물 중 하나 로, 검은 색 껍질의 삼각형 모양 형태로써 주로 가루로 가공 하여 소비되고 있다(Krkošková 등, 2005). 우리나라에서는 밥을 지을 때 섞어서 메밀밥을 하거나 곱게 가루를 내어 메밀 묵과 메밀국수, 메밀전병 등을 만드는 데 사용하며, 볶아서 메밀차로도 이용되고 있다. 외국의 경우는 스프, 팬케이크 및 스파게티 등을 만들 때 메밀가루를 밀가루 등에 첨가하여 사 용하고 있다(Choi, 2007, Lee 등, 1991; Maeng 등, 1990). 메 밀 속에는 다양한 영양소가 존재하며, 그 중 폴리페놀 성분으 로는 rutin, quercetin, isoquercetin, myricetin, caffeic acid 유 도체 등이 있어, 이들 화합물은 항산화 작용, 항균작용 등 생 체조절기능을 가지고 있다고 알려져 있다(Lee 등, 2014).

따라서 본 연구는 곡류의 일종인 메밀에 볶음 조건을 다르 게 하여 in vitro 소화계를 적용함으로써 볶음 메밀의 산화 방지 효과와 유지 산화 안정성에 관한 연구를 하고자 하였고, in vitro 소화계를 활용한 식품 개발 산업에 기초자료를 제공 하고자 하였다.

\section{재료 및 방법}

\section{실험 재료}

메밀은 강원도 평창군 봉평읍에서 재배한 보통 메밀 (Fagopyrum esculentum)을 구매하여 사용하였다. 메밀을 원 두 로스팅 기계(Gene café CBR-101, GENESIS Co., LTD, Ansan, Korea)로 $180^{\circ} \mathrm{C}$ 와 $200^{\circ} \mathrm{C}$ 에서 각각 10 분, 20 분 볶음 처리를 한 후 분쇄기(SP-7405S, Comac, Seongnam, Korea) 를 이용하여 분말 제조하였다.

\section{In vitro 소화계 적용 및 $80 \%$ 에탄올 추출물 제조}

In vitro digestion은 Werner와 Bohm(2011)의 방법과 $\mathrm{Ng}$ 와 See(2019)의 방법을 참고하여 진행하였다. 분쇄한 볶지 않은 메밀과 각각의 볶음 메밀 분말 $5 \mathrm{~g}$ 을 각각 삼각플라스 크에 넣은 후 $0.9 \% \mathrm{NaCl} 30 \mathrm{~mL}$ 를 취한 후 항온수조(BS-21 JEIO TECH, Daejeon, Korea) $37^{\circ} \mathrm{C}, 200 \mathrm{rpm}$ 에서 5 분간 혼 합시켰다. 그 후 소화기관인 입의 환경을 맞추기 위하여 20 $\mathrm{mg} / \mathrm{mL} \alpha$-amylase(Sigma-Aldrich Co., St. Louis, MO, USA) 를 $2 \mathrm{~mL}$ 취한 후 항온수조 $\left(37^{\circ} \mathrm{C}, 200 \mathrm{rpm}\right)$ 에서 5 분간 혼합 하였다. 위의 환경을 조성하기 위해 $0.1 \mathrm{M} \mathrm{HCl(Daejung,}$ Siheung, Korea)를 용매로 $\mathrm{pH}$ 를 조절하여 사용한 $40 \mathrm{mg} / \mathrm{mL}$ pepsin(Sigma-Aldrich Co.)을 $2 \mathrm{~mL}$ 취한 후 항온수조 $\left(37^{\circ} \mathrm{C}\right.$, $200 \mathrm{rpm})$ 에서 30 분간 혼합하였으며, 소장에서의 소화조건으 로 $\mathrm{pH}$ 유지를 위하여 $0.1 \mathrm{M} \mathrm{NaHCO}_{3}$ (Daejung)를 용매로 사 용한 $2 \mathrm{mg} / \mathrm{mL}$ pancreatin(Sigma-Aldrich Co.)과 $12 \mathrm{mg} / \mathrm{mL}$ bile extract(Sigma-Aldrich Co.) 시약을 $9 \mathrm{~mL}$ 취한 후 항온 수조 $\left(37^{\circ} \mathrm{C}, 200 \mathrm{rpm}\right)$ 에서 30 분간 혼합하였다. 이후 동결건조 (BFD85-F8, IlshinBiobase, Seoul, Korea)하여 분쇄하였으며 이후 $80 \%$ 에탄올(Daejung)을 이용하여 추출을 실시하였다. $80 \%$ 에탄올 추출은 분쇄된 시료와 그 시료 무게의 15 배의 $80 \%$ 에탄올을 혼합하여 진탕기(RS-1, JEIO TECH, Daejeon, Korea)에서 6시간 동안 $280 \mathrm{rpm}$ 으로 추출하였으며 추출물은 여과지(Whatman No.4, Maidstone, England)로 여과한 후 회전 감압농축(Rotavapor ${ }^{\circledR} \mathrm{R}-100, \mathrm{BU}$ CHI, Zollikofen, Switzerland) 을 거쳐 동결건조(BFD85-F8, IlshinBiobase) 하였다. 완성된 추출물은 $-20^{\circ} \mathrm{C}$ 에서 냉동 보관하며 실험에 사용하였다.

\section{$\mathrm{DPPH}$ 라디칼 소거활성 측정}

$\mathrm{DPPH}(2,2$-diphenyl-1-picrylhydrazyl) 라디칼 소거 활성은 $\operatorname{Kim}$ 과 $\operatorname{Kim}(2020)$ 의 방법을 참고하여 $0.1 \mathrm{mM}$ 의 $\mathrm{DPPH}$ (Sigma-Aldrich Co.) 용액 $0.75 \mathrm{~mL}$ 에 농도로 증류수에 희석한 시료를 각 $0.25 \mathrm{~mL}$ 씩 넣고 10 초간 혼합하고 30 분간 암실에서 반응시킨 후 UV/VIS spectrophotometer(Mega-U6000, Scinco, Seoul, Korea)를 이용하여 $517 \mathrm{~nm}$ 에서 흡광도를 측정하였다. 
$\mathrm{DPPH}$ 라디칼 소거 활성은 아래 공식으로 계산하였다.

DPPH radical scavenging activity $(\%)=$

$$
\frac{A_{c}-A_{s}}{A_{c}} \times 100
$$

$\mathrm{A}_{\mathrm{c}}$ : 대조군의 흡광도

$\mathrm{A}_{\mathrm{s}}$ : 시료의 흡광도

\section{ABTS 양이온 라디칼 소거활성 측정}

ABTS[2,2'-azino-bis(3-ethylbenzothiazoline-6-sulphonic acid)] 양이온 라디칼 소거 활성은 $\operatorname{Re}$ 등(1999)의 방법을 사 용하여 $7 \mathrm{mM}$ 의 ABTS(Sigma-Aldrich Co.)와 $2.45 \mathrm{mM}$ potassium persulfate(Sigma-Aldrich Co.)를 1:1로 혼합하여 암실에서 12 시간 반응시켜 $\mathrm{ABTS}$ 라디칼 양이온을 형성한 후 UV/VIS spectrophotometer(MegaU6000, Scinco)를 이용 하여 $734 \mathrm{~nm}$ 에서 흡광도가 $0.700( \pm 0.050)$ 이 되도록 에탄올 로 희석하여 사용하였다. 농도별 추출물 시료 $0.05 \mathrm{~mL}$ 와 에 탄올(Daejung)에 희석된 ABTS 용액 $1.9 \mathrm{~mL}$ 를 혼합한 후 10 분간 상온 암실에서 정치한 후 $734 \mathrm{~nm}$ 에서 흡광도를 측정하 였다. ABTS 양이온 라디칼 소거 활성은 아래 공식으로 계산 하였다.

ABTS cation radical scavenging activity $(\%)=$

$$
\frac{A_{c}-A_{s}}{A_{c}} \times 100
$$

$\mathrm{A}_{\mathrm{c}}$ : 대조군의 흡광도

$\mathrm{A}_{\mathrm{s}}$ : 시료의 흡광도

\section{FRAP 환원력 측정}

FRAP(ferric reducing antioxidant power) 환원력은 Benzie 와 Strain(1996)의 방법을 사용하여 $300 \mathrm{mM}$ sodium acetate buffer (pH 3.6)(Sigma-Aldrich Co.), $40 \mathrm{mM} \mathrm{HCl(Daejung)}$ 에 용해한 $10 \mathrm{mM}$ 2,4,6-tripyridyl-S-triazine(TPTZ)(SigmaAldrich Co.)용액과 $20 \mathrm{mM} \mathrm{FeCl}$ (Sigma-Aldrich Co.)를 각 각 $10: 1: 1(\mathrm{v} / \mathrm{v} / \mathrm{v})$ 의 비율로 혼합하여 $37^{\circ} \mathrm{C}$ 항온수조에서 15 분 간 평형시켜 FRAP 시약을 제조하였다. FRAP 시약 $0.9 \mathrm{~mL}$ 와 농도를 다르게 만든 시료 각 $0.03 \mathrm{~mL}$ 를 혼합하여 상온에 서 30분간 반응시킨 후 UV/VIS spectrophotometer(Mega$\mathrm{U} 6000, \mathrm{Scinco}$ )를 이용하여 $593 \mathrm{~nm}$ 에서 흡광도를 측정하였 다. 시료의 FRAP 환원력은 표준물질인 L-ascorbic acid (Sigma-Aldrich Co.)의 표준곡선으로부터 계산하였다.

\section{총페놀 함량 측정}

총페놀 함량(total phenolic contents, TPC)은 Folin과
Denis법(1912)을 사용하여 농도별로 희석한 시료 $0.05 \mathrm{~mL}$ 와 증류수 $0.8 \mathrm{~mL}$, 증류수와 $1: 1$ 로 희석한 Folin-Denis 시약 (Sigma-Aldrich Co.) $0.5 \mathrm{~mL}$ 를 30초간 혼합한 후 5 분간 정치 시켰다. 혼합한 용액에 Sodium carbonate(Sigma-Aldrich Co.) $0.1 \mathrm{~mL}$ 를 가하여 혼합한 후 상온에서 30 분간 정치한 후 UV/VIS spectrophotometer(Mega-U6000, Scinco)를 이용하 여 $725 \mathrm{~nm}$ 에서 흡광도를 측정하였다. 총페놀 함량은 표준물 질인 L-ascorbic acid(Sigma-Aldrich Co.)의 표준곡선으로부 터 계산하였다.

\section{ORAC가 측정}

ORAC(oxygen radical absorbance capacity)가 측정법은 Prior 등(2003)의 방법을 사용하여 $75 \mathrm{mM}$ phosphate buffer (pH 7.0)을 용매로 시료 희석 및 실험에 이용하였다. 300 $\mathrm{mM}$ 2,2'azo-bis (2-amidino-propane) dihydrochloride(AAPH) (FUJIFILM Wako Pure Chemical Corporation, Osaka, Japan) 와 $0.1 \mathrm{mM}$ fluorescein(VWR life science AMRESCO, Solon, $\mathrm{OH}, \mathrm{USA})$ 용액, 농도별로 희석한 시료를 $75 \mathrm{mM}$ phosphate buffer(Daejung)에 희석하여 사용하였다. 96-well plate에 AAPH $50 \mu \mathrm{L}$, fluorescein 용액 $150 \mu \mathrm{L}$, 농도별 시료 $50 \mu \mathrm{L}$ 를 넣어 준 후 fluorescence microplate reader(GeminiXPS, Moleculardevice, San Jose, CA, USA)를 이용하여 excitation $493 \mathrm{~nm}$, emission $515 \mathrm{~nm}$ 에서 40분간 매분 측정하였으며, 대조군으로는 trolox(Sigma-Aldrich Co.)를 사용하였다. 각 군의 커브면적(area under curve, $\mathrm{AUC}$ )을 측정한 후 fold가 로 나타내었다.

\section{시료 첨가 유지 제조}

유지 내에 시료의 고른 분산을 위하여 dimethyl sulfoxide (DMSO)에 녹여 옥수수 기름(Ottogi, Anyang, Korea)과 혼합 후 이를 dry oven(GISICO, Seoul, Korea)에서 각각 3, 6, 9시 간 동안 $100 \pm 5^{\circ} \mathrm{C}$ 의 열로 산화시켜 사용하였으며, 대조군은 $\mathrm{DMSO}$ 를 첨가하였다. 제조된 시료는 유지 산화를 방지하기 위해 $-20^{\circ} \mathrm{C}$ 에서 보관하며 실험하였다.

\section{$\mathrm{CDA}$ 가 및 $\rho-\mathrm{AV}$ 측정}

$\mathrm{CDA}$ (conjugated dienoic acid)가는 AOCS(1980) 법을 사 용하여 각각의 시료를 산화시킨 유지 시료 $0.02 \mathrm{~g}$ 과 isooctane (Daejung) $5 \mathrm{~mL}$ 를 혼합시켜 시료를 4,000 ppm의 농도로 희 석시켰다. 희석한 시료 $0.4 \mathrm{~mL}$ 에 isooctane $1.6 \mathrm{~mL}$ 를 넣어 한번 더 희석한 후 UV/VIS spectrophotometer(MegaU6000, Scinco)를 이용하여 $233 \mathrm{~nm}$ 에서 흡광도를 측정하였다.

$\rho-\mathrm{AV}(\rho$-anisidine value)의 경우 $\mathrm{AOCS}(1990)$ 법을 사용하 여 $0.25 \% \rho$-anisidine(Sigma-Aldrich Co.) 용액 $0.4 \mathrm{~mL}$ 와 시 
료를 4,000 ppm의 농도로 isooctane(Daejung)에 분산시킨 시 료 $2 \mathrm{~mL}$ 를 넣고 혼합하여 15 분간 암실에서 반응시킨 후 UV/VIS spectrophotometer(Mega-U6000, Scinco)를 이용하 여 $350 \mathrm{~nm}$ 에서 흡광도를 측정하여 $\rho-\mathrm{AV}$ 로 환산하였다.

\section{통계처리}

모든 실험의 시료 분석은 3회 반복하였으며, SPSS program (SPSS Inc., Chicago, IL, USA)을 이용하여 mean $\pm \mathrm{SD}$ 로 나타 내었다. 유의성 검정은 one-way ANOVA로 분석하여 $\mathrm{p}<0.05$ 수준에서 Duncan's multiple range test로 사후 검증하였으며, 항산화측정 방법간의 상관관계 분석을 위해 Pearson correlation 분석 $(\mathrm{p}<0.01)$ 을 사용하였다.

\section{결과 및 고찰}

\section{$\mathrm{DPPH}$ 라디칼 및 $\mathrm{ABTS}$ 양이온 라디칼 소거활성}

볶음 조건을 달리한 메밀에 각각 in vitro 소화과정을 적용 한 에탄올 추출물의 DPPH 라디칼 소거능은 다음 Fig. 1과 같 다. $1 \mathrm{mg} / \mathrm{mL}$ 의 농도에서 볶지 않은 메밀, $180^{\circ} \mathrm{C} 10$ 분, $180^{\circ} \mathrm{C}$ 20 분, $200^{\circ} \mathrm{C} 10$ 분, $200^{\circ} \mathrm{C} 20$ 분 볶음 군의 $\mathrm{DPPH}$ 라디칼 소거 능은 각각 $13.91 \%, 15.79 \%, 14.95 \%, 21.00 \%, 12.36 \%$ 로 나 타나, $200^{\circ} \mathrm{C} 10$ 분 볶음군이 유의적으로 가장 높은 라디칼 소 거능을 보였는데 $(\mathrm{p}<0.05), 200^{\circ} \mathrm{C} 10$ 분 볶음군이 볶지 않은 메밀군에 비해 $33.8 \%, 180^{\circ} \mathrm{C} 10$ 분 볶음군의 $24.8 \%, 180^{\circ} \mathrm{C}$ 20 분 볶음군의 $28.8 \%, 200^{\circ} \mathrm{C} 20$ 분 볶음군의 $41.1 \%$ 로 소거능 이 각각 증가되어 다양한 볶음 조건 중 $200^{\circ} \mathrm{C} 10$ 분이 유의적으

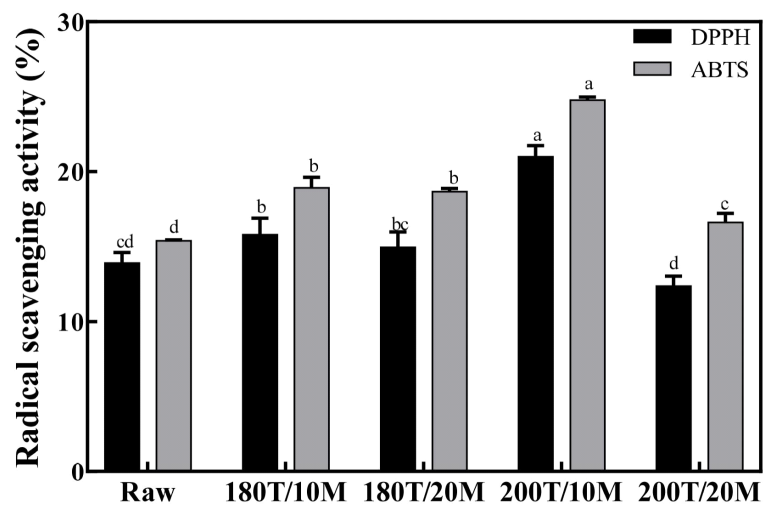

Fig. 1. Antioxidant activities of ethanol extract from in vitro digested buckwheat treated with different roasting temperature and time by DPPH and ABTS cation radical scavenging.

Raw: ethanol extract from raw buckwheat after in vitro digestion treatment. Number before $\mathrm{T}$ and $\mathrm{M}$ were temperature and treatment time, respectively. For example, $180 \mathrm{~T} / 10 \mathrm{M}$ were ethanol extract from in vitro digested buckwheat treated with roasting $180^{\circ} \mathrm{C}$ for $10 \mathrm{~min}$. Each value is mean $\pm \mathrm{SD}(\mathrm{n}=3)$. Different letters are significant differences at $\mathrm{p}<0.05$.
로 라디칼 소거능이 가장 우수한 것으로 관찰되었다 $(\mathrm{p}<0.05)$

또한 $\mathrm{ABTS}$ 양이온 라디칼 소거능의 경우, 볶지 않은 메밀 군, $180^{\circ} \mathrm{C} 10$ 분, $180^{\circ} \mathrm{C} 20$ 분, $200^{\circ} \mathrm{C} 10$ 분, $200^{\circ} \mathrm{C} 20$ 분 볶음군 이 각각 $15.39 \%, 18.92 \%, 18.67 \%, 24.76 \%, 16.61 \%$ 로 나타나 $\mathrm{DPPH}$ 라디칼 소거능의 결과와 비슷한 경향을 보여 $200^{\circ} \mathrm{C} 10$ 분 볶음군이 유의적으로 가장 높은 양이온 라디칼 소거 활성 을 보였다 $(\mathrm{p}<0.05)$. 볶음 처리를 하지 않은 메밀보다 볶음 처 리 공정을 진행한 메밀이 라디칼 소거능이 전반적으로 증가 함을 확인할 수 있었으며, 가열 온도와 시간이 증가함에 따라 대체로 라디칼 소거능이 증가하는 것을 알 수 있었다. 이러한 볶은 메밀의 라디칼 소거능에 대한 Ko 등(2012)의 연구에 의 하면 볶음 공정을 가한 온도와 시간이 증가함에 따라 전자공 여능이 증가하는데, 이는 가공 공정에 따른 증가된 melanoidin 에 의한 것으로 나타났다고 보고하였으며, Liu 등(2010)은 다 양한 색상을 가진 품종의 밀과 페놀성 화합물의 항산화 활성 을 조사하여 밀의 페놀성 화합물은 주로 페놀산, 플라보노이 드 및 안토시아닌으로 구성되어 있으며, 이런 곡물의 페놀함 량이 항산화 활성과 상관관계가 있다고 보고하였다. Lee 등 (2014)의 연구에 의하면 타타리 메밀을 가열처리했을 때 가 열시간이 증가함에 따라 라디칼 소거능이 증가하는 양상을 보였지만, $200^{\circ} \mathrm{C}$ 를 초과한 온도에서는 소거능이 유의적으로 감소되었다고 보고하였으며, Bhinder 등(2019) 또한 가열처 리한 타타리 메밀의 가열온도가 증가함에 따라 총 항산화 활 성이 감소하는 것을 관찰하였다. $\mathrm{Ng}$ 와 $\mathrm{See}(2019)$ 의 연구에 서는 in vitro 소화과정을 가한 12 가지 기능성 식물성 식품의 다수가 라디칼 소거활성이 증가되어, in vitro 소화과정이 식 물성 식품의 총 항산화 활성을 강화할 수 있을 것이라고 보고 하였다. 본 연구에서 메밀의 가열 조건 중 $200^{\circ} \mathrm{C} 10$ 분 볶음군 이 가장 우수한 라디칼 소거 활성을 보여 일정한 온도와 시간 내에서의 가열이 항산화 활성을 높일 수 있다는 것을 알 수 있었으며, 이를 통해 선행 연구들과 본 연구의 경향이 일치하 는 것을 확인하였다.

\section{총페놀 함량 및 FRAP 환원력}

총페놀 함량(TPC) 및 FRAP 환원력 결과는 Table 1과 같 다. 두 실험 모두 시간과 온도가 증가할수록 유의적으로 증가 하였다가 감소하는 경향을 나타내었다. TPC 측정 결과, 볶지 않은 메밀군 $9.61,180^{\circ} \mathrm{C} 10$ 분 볶음군 $9.86,180^{\circ} \mathrm{C} 20$ 분 볶음 군 $7.58,200^{\circ} \mathrm{C} 10$ 분 볶음군이 $13.14,200^{\circ} \mathrm{C} 20$ 분 볶음군 $9.71 \mu \mathrm{mol}$ tannic acid equivalent/g extract로 총페놀 함량이 다양한 볶음 조건 중에서 $200^{\circ} \mathrm{C} 10$ 분이 유의적으로 가장 높 은 함량을 보이는 것으로 관찰되었다 $(\mathrm{p}<0.05)$. 또한 FRAP 환 원력의 경우는 볶지 않은 메밀군, $180^{\circ} \mathrm{C} 10$ 분 볶음군, $180^{\circ} \mathrm{C}$ 20 분 볶음군, $200^{\circ} \mathrm{C} 10$ 분 볶음군, $200^{\circ} \mathrm{C} 20$ 분 볶음군은 각각 
Table 1. Total phenolics contents (TPC) and ferric reducing antioxidant power (FRAP) value in ethanol extract of in vitro digested buckwheat treated with different roasting temperature and time

\begin{tabular}{cccc}
\hline \multirow{2}{*}{ Sample } & $\mathrm{TPC}^{1)}$ & & FRAP $^{2)}$ \\
\cline { 2 - 2 } & $\begin{array}{c}(\mu \text { mol tannic acid } \\
\text { equivalent/g extract })\end{array}$ & & $\begin{array}{c}(\mu \text { mol ascorbic acid } \\
\text { equivalent/g extract })\end{array}$ \\
\hline Raw & $9.61 \pm 0.19^{\mathrm{b}}$ & & $43.35 \pm 1.61^{\mathrm{c}}$ \\
$180 \mathrm{~T} / 10 \mathrm{M}$ & $9.86 \pm 0.22^{\mathrm{b}}$ & & $38.00 \pm 1.16^{\mathrm{d}}$ \\
$180 \mathrm{~T} / 20 \mathrm{M}$ & $7.58 \pm 0.10^{\mathrm{c}}$ & & $36.31 \pm 0.79^{\mathrm{d}}$ \\
$200 \mathrm{~T} / 10 \mathrm{M}$ & $13.14 \pm 0.27^{\mathrm{a}}$ & & $56.49 \pm 1.91^{\mathrm{a}}$ \\
$200 \mathrm{~T} / 20 \mathrm{M}$ & $9.71 \pm 0.41^{\mathrm{b}}$ & & $50.79 \pm 0.69^{\mathrm{b}}$ \\
\hline
\end{tabular}

${ }^{1)} \mathrm{TPC}$, total phenolics contents.

${ }^{2}$ FRAP, ferric reducing antioxidant power.

Symbols were listed in the legend of Fig. 1. Each value is mean \pm SD

$(n=3)$. Different letters are significant differences at $\mathrm{p}<0.05$.

43.35, 38.00, 36.31, 56.49, $50.79 \mu$ mole ascorbic acid equivalent/g extract로 관찰되어 $\mathrm{TPC}$ 와 동일하게 $200^{\circ} \mathrm{C} 10$ 분 볶음군이 유의적으로 높은 환원력을 나타내었다 $(\mathrm{p}<0.05)$. Ismail 등(2004)의 연구에 따르면 비가열과 가열처리한 여러 종류의 채소의 페놀성 화합물을 비교하였을 때 가열 처리시 총 페놀성 화합물이 증가하며, Hong 등(1998)의 볶음처리에 따른 치커리의 항산화 관련 연구에서 가열 처리에 인한 페놀 성 화합물 함량이 증가하였는데, 이는 고분자 불용성 페놀 화 합물로부터 분리된 유리 페놀성 화합물이 생성되었기 때문이 라고 보고하였다. 또한 Chen 등(2020)은 in vitro 소화과정을 가한 볶은 참깨의 총페놀 함량과 총플라보노이드 함량이 크게 증가하였으며, 이는 체외소화로 인해 페놀과 플라보노이드의 화학적 결합의 변화를 일으킨 것으로 예측하였다. Prajapati 등 (2013)은 5가지 곡물을 조리할 때 항산화력과 페놀, 폴리페 놀 및 플라보노이드 함량이 향상되었으며, 화학 추출물보다 체외 소화를 이용한 추출물에서 총페놀 함량, 총플라보노이 드 함량, FRAP 환원력이 높았다고 보고하였다. 이와 같이 본 연구 결과를 종합해 보면 $200^{\circ} \mathrm{C} 10$ 분이 볶음조건이 가장 효 과적이었으며, 페놀 함량의 변화는 식품 속 페놀성 화합물이 가열에 의한 열과 in vitro 소화과정을 통한 소화효소의 물리 화학적 반응을 통해 일어난 것으로 판단된다. 이러한 페놀성 화합물의 변화가 FRAP 환원력에도 영향을 준 것으로 사료 되며, 페놀성 화합물을 효과적으로 증가시키기 위해서 효율 적인 열처리 온도와 시간 등의 조건이 필요하다는 것을 알 수 있었다.

\section{항산화 활성(ORAC가)}

페록시 라디칼(peroxyl radical, ROO·)을 이용하여 형광물
질인 fluorescence의 감소를 측정하는 방법으로 사람의 생체 반응 조건(37 $\mathrm{C}, \mathrm{pH}$ 7)으로 식품의 항산화 능력을 평가하기 위한 표준 방법으로 제안된 분석법이다(Prior 등, 2005). ORAC가 결과는 다음 Fig. 2 와 같다. 시료 $25 \mu \mathrm{g} / \mathrm{mL}$ 농도에 서 시료 무첨가 대조군에 비해 볶지 않은 메밀군은 1.72 배, $180^{\circ} \mathrm{C} 10$ 분 볶음군은 1.12 배, $180^{\circ} \mathrm{C} 20$ 분 볶음군은 1.38 배, $200^{\circ} \mathrm{C} 10$ 분 볶음군은 1.35 배, $200^{\circ} \mathrm{C} 20$ 분 볶음군에서 1.42 배 로 항산화력을 관찰할 수 있었다. ORAC가의 경우, 볶지 않은 메밀군이 유의적으로 가장 높은 항산화력을 보였다 $(\mathrm{p}<0.05)$. 또한 ORAC가 측정을 통해 대조군과 비교하였을 때 볶음 조 건은 $180^{\circ} \mathrm{C} 20$ 분, $200^{\circ} \mathrm{C} 10$ 분, $200^{\circ} \mathrm{C} 20$ 분에서 유의적으로 항산화력이 증가하는 것으로 나타났다 $(\mathrm{p}<0.05)$.

Małgorzata 등(2016)은 메밀 가루의 가열처리 시간에 따른 ORAC가를 측정하였을 때 메밀 가루를 30 분 이상 가열하였 더니, 오래 볶을수록 항산화 능력이 떨어졌다고 보고하였으 며, Jin 등(2015)의 연구에 의하면 열풍건조한 다래가 생과에 비해 ORAC가가 $23 \%$ 감소되었다고 보고하였다. 또한 붂은

(A)

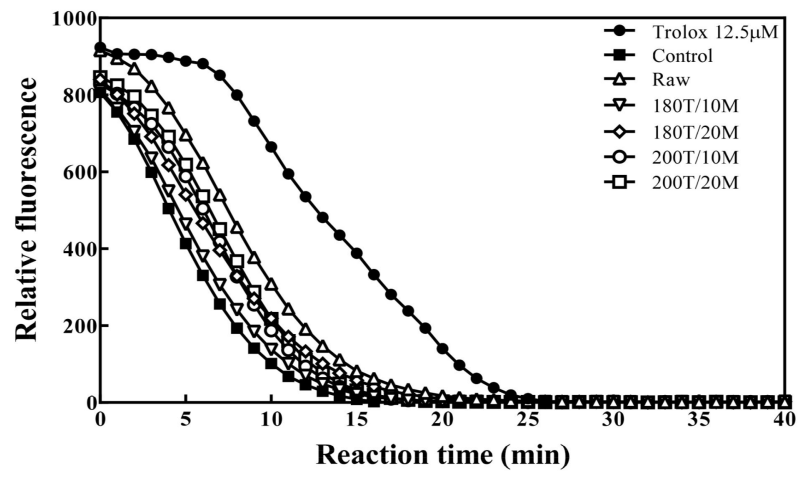

(B)

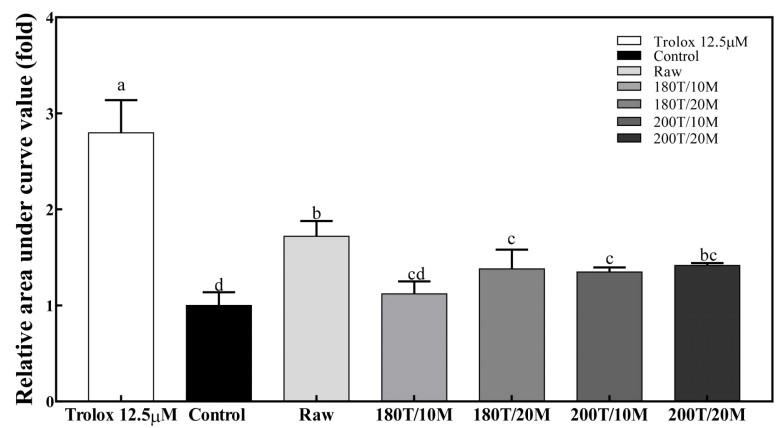

Fig. 2. Effect of ethanol extract from in vitro digested buckwheat treated with different roasting temperature and time on fluorescein elimination induced by AAPH.

(A) Fluorescein curve of ORAC value; (B) Relative ORAC values. Symbols were listed in the legend of Fig. 1. Each value is mean \pm SD $(n=3)$. Different letters are significant differences at $p<0.05$. 
카카오닙스의 ORAC가가 볶지 않은 카카오닙스에 비해 $10 \%$ 감소됨을 보고한 바 있다(Mazor 등, 2011). 반면, Song 등 (2018)은 가열 처리 시간이 증가할수록 심황색소의 AAPH peroxyl 라디칼 소거활성이 증가된다는 보고도 있었는데, 이 와 같이 가열조건에 따른 $\mathrm{ORAC}$ 가에 미치는 영향은 다양한 결과를 보이고 있다. 또한 본 연구에서 다른 항산화 분석법과 는 달리 볶지 않은 메밀군의 ORAC가가 높게 나타났는데, 이 는 항산화물질이 직접적으로 발색에 영향을 미치는 기존의 항산화측정 방법과는 달리 ORAC가 분석법의 경우 실시간 형광물질의 변화를 간접측정하여 항산화력을 확인하는 것 (Prior 등, 2003)으로 원리적인 차이가 있어 이로 인한 것으로 사료된다.

\section{항산화 활성 측정 방법과의 상관관계 분석}

항산화 성분과 활성의 상관관계 분석의 결과는 Table 2 와 같다. 총폴리페놀 함량과 $\mathrm{DPPH}$ 라디칼 소거능, $\mathrm{ABTS}$ 양이 온 라디칼 소거능, $\mathrm{FRAP}$ 환원력은 각각 $\mathrm{R}^{2}=0.729(\mathrm{p}<0.001)$, $\mathrm{R}^{2}=0.716(\mathrm{p}<0.001), \mathrm{R}^{2}=0.824(\mathrm{p}<0.001)$ 로 가장 많은 분석과 양의 상관관계를 가지고 있었으며, DPPH 라디칼 소거능은 ABTS 양이온 소거능과 $\mathrm{R}^{2}=0.913(\mathrm{p}<0.001)$ 으로 가장 높은 양 의 상관관계를 나타내었다. 총폴리페놀 함량 측정과 $\mathrm{DPPH}$, $\mathrm{ABTS}, \mathrm{FRAP}$ 환원력에서의 양의 상관관계는 열처리로 인하 여 항산화 효과가 있는 대표적인 물질인 페놀성 화합물의 증 가로 기인한 것으로 생각되며, 이는 Kwak 등(2013)의 열처 리한 현미 추출물에 관한 연구에서 일정한 열처리를 실시한 시료가 항산화 활성과 총플라보노이드 함량의 변화가 생겼으 며 이는 총페놀 함량 분석 결과와 높은 상관관계가 있었다고 보고한 연구와 유사한 경향을 보였다.

\section{Conjugated dienoic acid(CDA)가 및 $\rho$-anisidine value $(\rho-A V)$}

유지가 산화되면서 생성되는 공액 이중결합을 측정하는
방법인 $\mathrm{CDA}$ 가 측정 결과는 Fig. 3과 같다. $1,000 \mathrm{mg} / \mathrm{kg}$ 농 도에서 $180^{\circ} \mathrm{C}$ 에서 40 분, 60 분, 80 분을 산화시켰을 때, 전반적 으로 40 분, 60 분까지는 시료를 첨가하지 않은 대조군에 비해 시료 첨가군들이 유지산화 안정에 영향을 미치지 않는 것으 로 나타났으나, 80 분에서는 대조군에 비해 시료 첨가군들이 유의적으로 유지산화를 안정화시키는 경향을 보였다 $(\mathrm{p}<0.05)$. 80 분에서 최종 $\mathrm{CDA}$ 가는 시료 무첨가 대조군은 $0.71 \%$, 볶지 않은 메밀은 $0.69 \%, 180^{\circ} \mathrm{C} 10$ 분 볶음 군은 $0.64 \%, 180^{\circ} \mathrm{C} 20$ 분 볶음 군은 $0.65 \%, 200^{\circ} \mathrm{C} 10$ 분 볶음 군은 $0.63 \%, 200^{\circ} \mathrm{C}$ 20 분 볶음 군은 $0.65 \%$ 로 나타났다. 시료 무첨가 대조군에 비 해 볶지 않은 메밀, $180^{\circ} \mathrm{C} 10$ 분, $180^{\circ} \mathrm{C} 20$ 분, $200^{\circ} \mathrm{C} 10$ 분, $200^{\circ} \mathrm{C} 20$ 분 볶음 군이 각각 $2.82 \%, 9.86 \%, 11.27 \%, 8.45 \%$ 감소된 값을 관찰할 수 있었으며, 볶지 않은 메밀군과 볶음군 모두 유의적으로 감소를 보였다 $(\mathrm{p}<0.05)$. 이를 통해 다양한 볶음 조건 중에서도 $200^{\circ} \mathrm{C} 10$ 분이 유지 산화물인 공액 이중

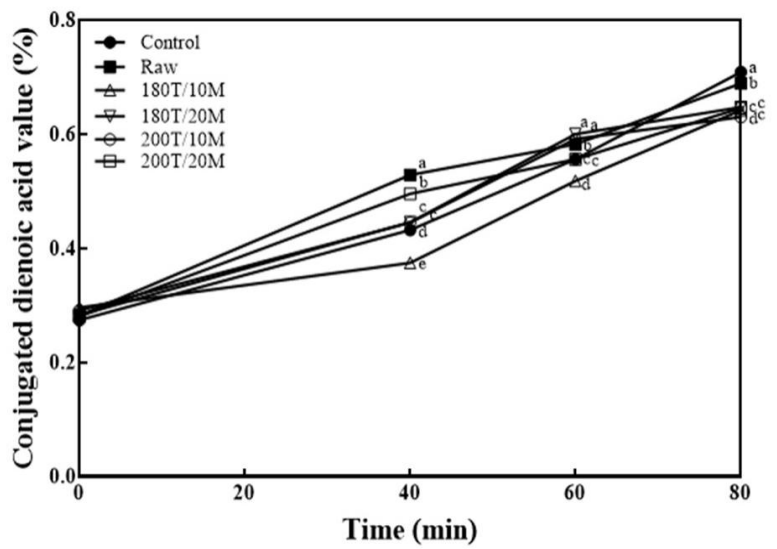

Fig. 3. Conjugated dienoic acid value of heated com oil at $180^{\circ} \mathrm{C}$ containing ethanol extract from in vitro digested buckwheat treated with different roasting temperature and time.

Symbols were listed in the legend of Fig. 1. Each value is mean \pm SD $(n=3)$. Different letters are significant differences at $p<0.05$.

Table 2. Pearson's correlation coefficients between total phenolics contents and antioxidant properties

\begin{tabular}{cccccc}
\hline \multirow{2}{*}{ Factor } & \multicolumn{5}{c}{ Pearson's correlation coefficients (r) } \\
\cline { 2 - 5 } & DPPH & ABTS & TPC & FRAP & ORAC \\
\hline DPPH & 1 & & & & \\
ABTS & $0.913^{* *}$ & 1 & & & \\
TPC & $0.729^{* *}$ & $0.716^{* *}$ & 1 & 1 & 1 \\
FRAP & 0.418 & 0.497 & $0.824^{* *}$ & 0.155 & 1 \\
ORAC & -0.234 & -0.436 & -0.099 & & \\
\hline
\end{tabular}

\footnotetext{
${ }^{* *}$ Significant at $\mathrm{p}<0.01$.
} 
결합이 가장 적게 생성됨을 알 수 있었다.

또한, 산화된 유지의 이차 산화 생성물을 측정하는 $\rho-\mathrm{AV}$ 의 실험결과는 Fig. 4 와 같다. $\mathrm{CDA}$ 와 마찬가지로 동일한 $1,000 \mathrm{mg} / \mathrm{kg}$ 농도에서 $180^{\circ} \mathrm{C}$ 에서 40 분, 60 분, 80 분을 산화시 켰을 때, 40 분에서는 시료 첨가군이 시료를 첨가하지 않은 대 조군과 비교하였을 때, 전반적으로 높은 값을 보였으나, 60 분 과 80 분에서는 시료 첨가군이 대조군보다 전체적으로 낮은 값을 보여 유지산화 안정성에 유의적인 영향을 관찰할 수 있 었다 $(\mathrm{p}<0.05)$. 시료 무첨가 대조군에 비해 볶지 않은 메밀, $180^{\circ} \mathrm{C} 10$ 분, $180^{\circ} \mathrm{C} 20$ 분, $200^{\circ} \mathrm{C} 10$ 분, $200^{\circ} \mathrm{C} 20$ 분 볶음 군이 각각 $118.85,109.78,94.80,103.50,89.25,95.50$ 로 나타나, $\mathrm{CDA}$ 실험결과와 비슷한 양상을 나타내어 $200^{\circ} \mathrm{C} 10$ 분처리로 인해 가장 우수한 이차 유지 산화생성물 억제를 관찰할 수 있었다 $(\mathrm{p}<0.05)$.

이러한 식품모델의 유지산화 안정성에 관한 연구를 살펴 보면, Hęs 등(2017)은 메밀 껍질 추출물이 첨가된 미트볼을 기름에 튀겨 장시간 냉동보관 후 지질 산화를 측정하여 산화 방지제인 BHT(butylated hydroxytoluene)와 비교하였을 때 우수한 과산화물 및 TBARS 억제력을 보여주었으며, 이러한 결과는 메밀 껍질 추출물에 존재하는 페놀성 화합물과 연관 이 있다고 보고하였다. Suri 등(2019)은 블랙커민 종자를 가 열 처리하면서 lipase와 lipoxygenase를 비활성화시켜 산패 지표인 산가(acid value)를 감소시킨 것을 관찰하였다. 또한 Lee 등(2010)의 연구에 의하면 온도와 시간별로 볶음 처리한 참깨에서 추출한 기름의 산화안정성을 측정하였을 때 대부분 의 볶음 처리군에서 온도가 높고 시간이 길어질수록 볶음처 리하지 않은 실험군보다 높은 산화안전성을 나타냈다고 보고

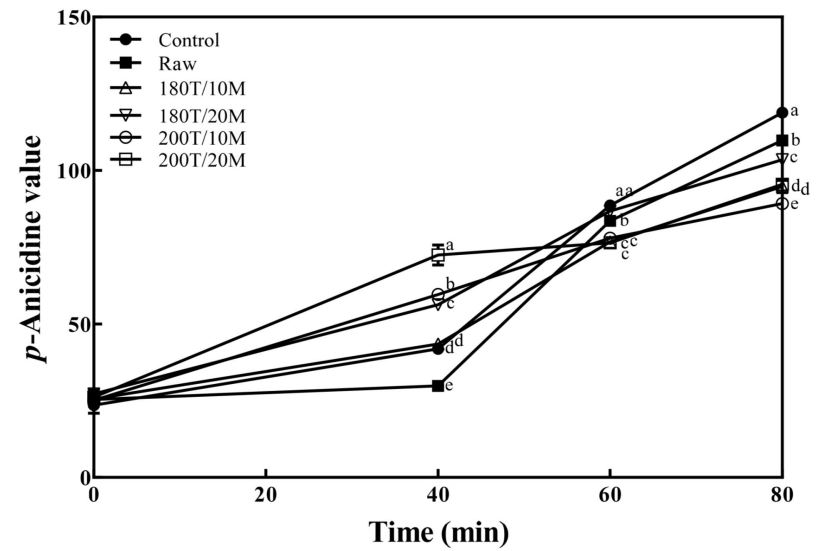

Fig. 4. $\rho$-Anisidine value of heated com oil at $180^{\circ} \mathrm{C}$ containing ethanol extract from in vitro digested buckwheat treated with different roasting temperature and time.

Symbols were listed in the legend of Fig. 1. Each value is mean \pm SD $(n=3)$. Different letters are significant differences at $\mathrm{p}<0.05$.
하였다. Sun과 $\mathrm{Ho}(2005)$ 는 메밀 추출물 속 천연산화방지제 가 합성산화방지제를 대체하여 지질 식품의 산화를 방지할 수 있을 것이라고 보고하였다. 이를 통해 본 연구의 결과는 메밀 속 페놀성 화합물이 유지의 산화를 지연시키는 것으로 판단된다.

\section{요 약}

본 연구는 in vitro digestive system 적용과 붂음 조건에 따른 메밀의 항산화 활성 및 유지산화 안정성에 대한 효과를 살펴보고자 하였다. 산화 방지 효과를 측정한 실험결과 중 활 성이 가장 높은 시료 처리 군을 보았을 때, DPPH 및 $\mathrm{ABTS}$ 양이온 라디칼 소거능 결과, $200^{\circ} \mathrm{C} 10$ 분 군에서 각각 $21.00 \%$, $24.76 \%$ 로 가장 높은 소거능을 보였다 $(\mathrm{p}<0.05)$. 총 페놀함량 결 과 또한 $200^{\circ} \mathrm{C} 10$ 분 군이 $13.14 \mu \mathrm{mol}$ tannic acid equivalent $/ \mathrm{g}$ extract로 측정되었으며, FRAP 환원력 측정에서도 $200^{\circ} \mathrm{C} 10$ 분 군이 $56.49 \mu \mathrm{mol}$ ascorbic acid equivalent/g extract로 관 찰되었다. $\mathrm{ORAC}$ 가 결과 볶음군 중 볶음 조건이 $180^{\circ} \mathrm{C} 20$ 분, $200^{\circ} \mathrm{C} 10$ 분, $200^{\circ} \mathrm{C} 20$ 분에서 유의적으로 항산화력 증가를 관 찰할 수 있었다 $(\mathrm{p}<0.05)$. 또한 항산화 성분과 활성의 상관관 계에서 볶음으로 인한 페놀 화합물의 증가로 항산화 활성과 의 유의적 상관관계를 확인할 수 있었다 $(\mathrm{p}<0.01)$. 유지 산화 안정성 평가를 실시한 결과, 유지 산화물인 CDA가를 측정하 였을 때 $200^{\circ} \mathrm{C} 10$ 분 볶음 군이 시료 무첨가 대조군의 CDA양 에 비해 $11.27 \%$ 감소된 양이 생성되었으며, 2차 산화 생성물 을 $\rho-\mathrm{AV}$ 로 측정하였을 때 $24.91 \%$ 감소됨을 관찰할 수 있었 다. 이에 본 연구는 in vitro 소화계를 적용한 $200^{\circ} \mathrm{C} 10$ 분 볶 음군이 우수한 항산화 활성과 유지 산화 안정성을 보였으며, in vitro 소화계를 통한 식품으로의 적용 가능성과 메밀의 볶 음 온도와 시간에 따라 항산화 활성에 폴리페놀 함량의 영향 이 다를 수 있어 곡류의 기능성 연구에 활용할 수 있는 자료 제공을 할 수 있을 것으로 생각된다.

\section{감사의 글}

This research was supported by Basic Science Research Program through the National Research Foundation of Korea (NRF) funded by the Ministry of Education(NRF-2018R1D1 A3B07045467).

\section{Conflict of interests}

The authors declare no potential conflict of interest. 


\section{ORCID}

Hyun-Gyeong Bae https://orcid.org/0000-0002-8406-6984

Mi-Ja Kim https://orcid.org/0000-0003-0261-8384

\section{References}

AOCS. Official and Tentative Methods of the AOCS. 3rd ed, Method Cd 18-90, American Oil Chemists' Society Press. Champaign, IL, USA (1980)

AOCS. Official and Tentative Methods of the AOCS. 4th ed, Method Ti la-64, American Oil Chemists' Society Press. Champaign, IL, USA (1990)

Benzie IFF, Strain JJ. The ferric reducing ability of plasma (FRAP) as a measure of "antioxidant power": The FRAP assay. Anal Biochem, 239, 70-76 (1996)

Bhinder S, Singh B, Kaur A, Singh N, Kaur M, Kumari S, Yadav MP. Effect of infrared roasting on antioxidant activity, phenolic composition and Maillard reaction products of tartary buckwheat varieties. Food Chem, 285, 240-251 (2019)

Boisen S, Eggum BO. Critical evaluation of in vitro methods for estimating digestibility in simple-stomach animals. Nutr Res Rev, 4, 141-162 (1991)

Chen Y, Lin H, Lin M, Zheng Y, Chen J. Effect of roasting and in vitro digestion on phenolic profiles and antioxidant activity of water-soluble extracts from sesame. Food Chem Toxicol, 139, 111239 (2020)

Cho KM, Joo OS. Enhances antioxidant effect of purple sweet potato by roasting. Korean J Food Preserv, 19, 735-743 (2012)

Choi SH. Volatile flavor components of buckwheat-green tea. J Life Sci, 17, 1111-1114 (2007)

Coles LT, Moughan PJ, Darragh AJ. In vitro digestion and fermentation methods, including gas production techniques, as applied to nutritive evaluation of foods in the hindgut of humans and other simple-stomached animals. Anim Feed Sci Tech, 123-124, 421-444 (2005)

Dewanto V, Wu X, Adom KK, Liu RH. Thermal processing enhances the nutritional value of tomatoes by increasing total antioxidant activity. J Agric Food Chem, 50, 30103014 (2002)

Folin O, Denis W. A new colorimetric method for the determination of vanillin in flavoring extracts. Ind Eng
Chem, 4, 670-672 (1912)

Hes M, Szwengiel A, Dziedzic K, Le Thanh-Blicharz J, Kmiecik D, Gorecka D. The effect of buckwheat hull extract on lipid oxidation in frozen-stored meat products. J Food Sci, 82, 882-889 (2017)

Hong MJ, Lee GD, Kim HK, Kwon JH. Changes in functional and sensory properties of chicory roots induced by roasting processes. Korean J Food Sci Technol, 30, 413-418 (1998)

Hur SJ, Decker EA, McClements DJ. Influence of initial emulsifier type on microstructural changes occurring in emulsified lipids during in vitro digestion. Food Chem, 114, 253-262 (2009)

Hur SJ, Lee SK, Kim YC, Choi IW. Development of in vitro human digestion models for health functional food research. Korean Soc Food Sci Technol, 45, 40-49 (2012)

Ismail A, Marjan ZM, Foong CW. Total antioxidant activity and phenolic content in selected vegetables. Food Chem, 87, 581-586 (2004)

Jin CR, Cho CH Tae-Gyu Nam TG, Cho YS, Kim DO. Effects of hot air drying on the antioxidant capacity of Actinidia arguta $\times$ A. deliciosa cv. mansoo, a hardy kiwifruit. Korean J Food Sci Technol, 47, 539-543 (2015)

Kim MA, Kim MJ. Isoflavone profiles and antioxidant properties in different parts of soybean sprout. J Food Sci, 85, 689-695 (2020)

Ko JY, Woo KS, Song SB, Seo HI, Kim HY, Kim J, Kwak DY, Oh IS. Physicochemical characteristics of sorghum tea according to milling type and pan-fried time. J Korean Soc Food Sci Nutr, 41, 1546-1553 (2012)

Krkoskova B, Mrazova Z. Prophylactic components of buckwheat. Food Res Int, 38, 561-568 (2005)

Kwak J, Oh SK, Kim DJ, Lee JH, Yoon MR, Kim HW, Lee JS. Effects of heat treated brown rice on total phenolics and antioxidant activities. J Korean Soc Food Sci Nutr, 42, 534-541 (2013)

Lee MH, Cho JH, Kim JC, Kim BK. Effect of roasting conditions on the antioxidant activities of tartary buckwheat. J Korean Soc Food Sci Nutr, 46, 390-393 (2014)

Lee SW, Jeung MK, Park MH, Lee SY, Lee JH. Effects of roasting conditions of sesame seeds on the oxidative stabilityof pressed oil during thermal oxidation. Food 
Chem, 118, 681-685 (2010)

Lee SY, Shim HH, Ham SS, Rhee HI, Choi YS, Oh SY.

The nutritional components of buckwheat flours and physicochemical properties of freeze - dried buckwheat noodles. J Korean Soc Food Sci Nutr, 20, 354-362 (1991)

Liu Q, Qiu Y, Beta T. Comparison of antioxidant activities of different colored wheat grains and analysis of phenolic compounds. J Agric Food Chem, 58, 9235-9241 (2010)

Lucas-Gonzalez R, Viuda-Martos M, Perez-Alvarez JA, Fernandez-Lopez J. In vitro digestion models suitable for foods: Opportunities for new fields of application and challenges. Food Res Int, 107, 423-436 (2018)

Maeng YS, Park HK, Kwon TB. Analysis of rutin contents in buckwheat and buckwheat foods. Korean J Food Sci Technol, 22, $732-737$ (1990)

Majcher MA, Klensporf-Pawlik D, Dziadas M, Jelen HH. Identification of aroma active compounds of cereal coffee brew and its roasted ingredients. J Agric Food Chem, 61, 2648-2654 (2013)

Malgorzata W, Konrad PM, Zielinski H. Effect of roasting time of buckwheat groats on the formation of Maillard reaction products and antioxidant capacity. Food Chem, 196, 355-358 (2016)

Mazor Jolic S, Radojcic Redovnikovic I, Markovic K, Ivanec Sipusic D, Delonga K. Changes of phenolic compounds and antioxidant capacity in cocoa beans processing. Int J Food Sci Technol, 46, 1793-1800 (2011)

Monro JA, Wallace A, Mishra S, Eady S, Willis JA, Scott RS, Hedderley D. Relative glycaemic impact of customarily consumed portions of eighty-three foods measured by digesting in vitro and adjusting for food mass and apparent glucose disposal. Brit J Nutr, 104, 407-417 (2010)

$\mathrm{Ng} \mathrm{ZX}$, See AN. Effect of in vitro digestion on the total polyphenol and flavonoid, antioxidant activity and carbohydrate hydrolyzing enzymes inhibitory potential of selected functional plant-based foods. J Food Process Pres, 43, e13903 (2019)

Prajapati MR, Patel V, Parekh T, Subhash R. Effect of in bioprocessing on antioxidant activity of selected cereals. Asian J Plant Sci Res, 3, 66-72 (2013)

Prior RL, Hoang H, Gu L, Wu X, Bacchiocca M, Howard L, Hampsch-Woodill M, Huang D, Ou B, Jacob R. Assays for hydrophilic and lipophilic antioxidant capacity (oxygen radical absorbance capacity $\left(\mathrm{ORAC}_{\mathrm{FL}}\right)$ ) of plasma and other biological and food samples. J Agric Food Chem, 51, 3273-3279 (2003)

Prior RL, Wu W, Schaich K. Standardized methods for the determination of antioxidant capacity and phenolics in foods and dietary supplements. J Agric Food Chem, 53, 4290-4302 (2005)

Re R, Pellegrini N, Proteggente A, Pannala A, Yang M, Rice-Evans C. Antioxidant activity applying an improved ABTS radical cation decolorization assay. Free Radical Biol Med, 26, 1231-1237 (1999)

Schlormann W, Zetzmann S, Wiege B, Haase N, Greiling A, Lorkowski S, Glei M. Impact of different roasting conditions on sensory properties and health-related compounds of oat products. Food Chem, 307, 125548 (2020)

Song ES, Kang SM, Hong JI. Changes in chemical properties, antioxidant activities, and cytotoxicity of turmeric pigments by thermal process. Korean J Food Sci Technol, 50, 21-27 (2018)

Sun T, Ho CT. Antioxidant activities of buckwheat extracts. Food Chem, 90, 743-749 (2005)

Suri K, Singh B, Kaur A, Yadav MP, Singh N. Impact of infrared and dry air roasting on the oxidative stability, fatty acid composition, maillard reaction products and other chemical properties of black cumin (Nigella sativa L.) seed oil. Food Chem, 295, $537-547$ (2019)

Werner S, Bohm V. Bioaccessibility of carotenoids and vitamin e from pasta: Evaluation of an in vitro digestion model. J Agric Food Chem, 59, 1163-1170 (2011)

Yu J, Ahmendna M, Goktepe I. Effects of processing methods and extraction solvents on concentration and antioxidant activity of peanut skin phenolics. Food Chem, 90, 199-206 (2005) 